\title{
Probability of Efficiency: Statistical Implications That Lead Firms to Achieve a Minimal and Sufficient "Return-On-Investment"
}

\author{
Marco Muscettola ${ }^{1}$ \\ ${ }^{1}$ Credit Risk Manager - Independent researcher, Italy \\ Correspondence: Marco Muscettola, via Generale Scattaglia, 30/B - 70010 Adelfia (BA), Italy. E-mail: \\ marcomuscettola@hotmail.com
}

Received: September 16, 2014

Accepted: September 30, 2014

Online Published: October 16, 2014

doi:10.5430/jms.v5n4p26

URL: http://dx.doi.org/10.5430/jms.v5n4p26

\begin{abstract}
After clarifying the relationship between Return-On-Investment (ROI) and the possibility of default, the research sets a minimum level of this ratio, which can generally be assigned to an efficient and healthy firm. From this step we start to comprehend which are the economic and financial variables that owned the firms, three years before, reaching that minimum level of ROI. With logistics methodology and a large sample of 5,388 Italian SMEs, a rating model may be built to predict the probability of efficiency and will be studied accounting variables that lead a firm with more possibilities to be "prospective efficient". Results support the view of the importance of capital structure and operating profitability ratios.
\end{abstract}

Keywords: probability of efficiency, SME finance, rating model

\section{Introduction}

It is generally accepted that SMEs (small and medium-sized businesses) are the real engine of the European economy and the essential mechanism to the employment of our countries. This relies on the number of firms and on the relevance of each company in the local context. On the other hand, in economic downturn, it is downright indubitable that the SMEs are encountering several difficulties to walk a path of growth. And that, most likely, also for their financial structuring (itself a result of different economic and social conditions). Precisely for the particular historical moment, the SMEs play a vital role in the exit off the economic and financial crisis and various is the attention of governments and international organizations in order to understand what levers can move to jump-start the economy of those SMEs.

The essay stems from its aim to examine some of the axioms of economic theory and literature, starting by a different point of view. After clarifying the relationship between the Return on investment and the possibility of default, the research sets a minimum level of this indicator, which can generally be assigned to an efficient and healthy firm. From this step we start to comprehend what are the economic and financial variables that owned the firms three years before reaching that minimum level of Return-On-Investment (ROI).

In recent years several studies have been focused in analyzing the relationship between financial structure of firms and insolvency risk or to identify the optimal capital structure. On the other hand, in the literature theories, about the links between efficiency of the sources of investment and economic aspects of the firms, are fragmented and often there is not a full explanation and acknowledged outline of the mutual dependencies. In addition to the above, at least for our knowledge, works on samples of SMEs, in order to verify the dependency between profitability ratios and the level of solvency of the firms (Muscettola, 2014b), have never been performed hitherto.

The purpose of this dissertation, therefore, is to evaluate, scientifically and analytically, the interdependencies between the return on investment and the profitable growth of the companies over time and, on the other hand, if it is possible to outline an ideal mix of risk capital and debt that lead the firm to a real efficiency.

In order to better analyze the firms in the sample it was decided to lengthen the investigation time up to three years following the collection of data thereby building a new rating model that has less stickiness and less external influences with the economic condition of the economy. In addition, a model with a longer time horizon is also more functional.

The differences from other similar models are not to be overlooked, because the scientific approach to the problem 
and the statistical methodology used radically changed. Compared to a classical model of rating, in fact, the revelation of examination is turned upside down and optimistic and the longer time-frame plans the specific research to grasp the fundamental relationship between the financial structure and the gradual growth of the same firm (Muscettola \& Naccarato, 2013). Many of the most supported recent studies have dealt with the importance and, above all, the differences between the approaches "point in time" and "through-the-cycle" of the rating model, leaving a grey area for interpretation and for opposing factions (Muscettola \& Pietrovito, 2012b).

Summarizing, the purpose of this study is to analyze the economic problem of the assessment of business risk through a positive approach (search for calculation of sufficient level of ROI instead for the probability of default), a longer observation period (three years instead of one) analyzing Italian SMEs with a different rating philosophy and projected it into the future. Finally it is necessary to add that building a model of corporate valuation using only SMEs in the sample is significantly different and often conflicting weights with respect to a generic model suitable for all type of firms. The SMEs, in fact, are on average more "opaque" and no longer bound by the banking system compared to larger companies. SMEs, furthermore, have a lower independence and are less influenced by the macroeconomic situation.

With respect to previous studies that have investigated the link between ROI and other business components, many authors observe a significantly negative relationship between return on investments and liquidity and also significantly negative relationship between total debt and profitability (Chatterjee, 2010). The implication is that, profitability of firms increase when they improve upon their working capital management. Particularly, holding highly liquid assets is important as it significantly enhances firms' profitability. This is because assets can easily and quickly be sold off and the revenue re-invested in other relatively higher short-term assets and coupled with the fact that it also prevents court actions and its associated cost emanating from the firm's inability to pay its short-term creditors.

\section{Conceptual Definitions: Efficiency}

The notion of economic efficiency drifts from the microeconomic conception of the firm. Under these suppositions, the final goal of any company is to maximize profits by minimizing costs and maximizing revenues. This is the traditional micro-economic philosophy (Farrell, 1957) which continued to produce a framework to examine firms that are not efficient and to compare firms to "best practice" efficient frontiers molded by the principal companies in a sector.

Many studies are directed to compare firms in the industry to the pursuit of efficiency. The most significant offerings in this literature were the progress of stochastic efficient frontiers (Note 1) by Aigner et al (1977), Battese and Corra (1977), Meeusen and Van den Broeck (1977), Greene, (2008) McNichols and Stubben (2008) and Beatty et al. (2010) and the progress of nonparametric mathematical frontiers by Charnes e al (1978) Cooper et al (2004) and Färe et al (2008).

Conventionally, theoretical contribution has been done using accounting ratios. With the advancement of frontier efficiency the outmoded approaches have become commonly obsolete, particularly to studies concerning book values rather than market values (Cummins \& Weiss, 2012). Several papers investigate how to improve investment efficiency. The empirical surveys (Muscettola, 2013) furthermore imply that a high level of debt use is unhealthy for the financial success of the firm whereas increases in sales encourage firm profitability: This leads to consider the solvency and success of firm closely linked to the ROI. Among other accounting researches on corporate efficiency, managerial performance inclinations may not only mark a firm's financing choices but also influence its investment results. Myers and Majluf (1984) theorize that the presence of information asymmetry will arouse slanted investments, so decreasing the efficiency of capital investments. Jensen (1986), using the concept of agency cost, calculates the effects on efficiency in companies with managers at odds with shareholders. Kanodia et al (2005) examine the economic significances of the interaction between noisy accounting measures and the investment profitability. Biddle and Hilary (2006) and Biddle et al. (2009) demonstrate the relationship between efficiency and quality information (asymmetries) through an accounting approach. Chen et al (2007) seek to apprehend whether managerial optimism distresses the corporate efficiency and in what conditions managerial optimism minimizes investment distortion.

Summarizing, efficiency means, therefore, to maximize profits: profit efficiency. Firms that realize full technical efficiency (efficient firms) are the same that minimize inputs conditional on outputs (Note 2). To achieve efficiency, the firm must necessarily start from estimating cost efficiency trying the technique of cost minimization. On the other hand, if it is simpler, firm can start with the revenue maximization. It is also important to select the optimal mixture of inputs and choosing the optimal combination of outputs: allocative efficiency. However efficiency is measured 
comparative to best practice frontiers involving of the prevailing firms in the industry.

In all the studies mentioned above there is not the contemporary research of corporate efficiency as opposed to insolvency, and most importantly, it is not clear what would be a valid indicator of efficiency and what are the conditions to achieve it. This paper aims to partially fill these gaps in academic literature.

\section{Conceptual Definitions: Return on Investment (ROI)}

Return-On-Investment (ROI) is surely one of the most important ratios to understand. It expresses the profitability of the capital invested in the firm and it is, therefore, synonymous with profitability and efficiency. It is a measure of managerial effectiveness by linking investment and earnings. More income the company is able to create with capital available more ROI will be high and, therefore, the firm profitable. It can be applied to a number of circumstances: estimation of a firm productivity, a product line, a specific investment or a branch.

"Return on investment" (ROI), more exactly, compares the income produced (effect) to invested capital (cause) explaining the firm's ability to work. It, most importantly, denotes the level of convenience in having used specific funds.

Return on investment $=$ (gain from investment - cost of investment $) /$ cost of investment or more simply:

$$
\text { ROI }=\frac{\text { Ebit }}{\text { Total investment }} \times 100
$$

As you read, the ROI equation relates the items that have different nature and composition. On numerator (measure of income) there is the income report as a stream, on the other hand, denominator (measure of investment) is a stock of capital. It is interesting, by a conceptual point of view, to understand that firm has been able to achieve the income flow through a specific amount of capital stock.

There are several ways to calculate the equation of ROI (see Shall \& Haley, 1991, Polimeni et al 1991 or Block \& Hirt 2002, for example). More correct would be the formula for ROI, as an indicator of capital invested in the firm, with the breakdown of the balance sheet of the company with an organization methodology. In the denominator, therefore, would fit what should be the operating capital. In the numerator would fit only the income generated by the operations of the company. In this way it will be possible to quantify precisely the efficiency of operations. The original meaning of ROI, to remember it, is to understand the productivity of capital invested in operations. Some items of balance sheet assets, such as cash or financial assets, are not included in invested capital. They logically, cannot be regarded equally the resources invested in the core business. Cash resources, in fact, are defined as such because they remain available to the firm but, at the time, not used in a productive manner and, therefore, unvested (Muscettola \& Gallo, 2008). The denominator (invested capital) is just calculated as the average of expressions and values with the previous year (Dominiak, 1985). It will be appropriate, then, at least a normalization of these data by calculating an average of the initial capital invested and final capital. At the time of calculation, most of the firm uses the simplest version of ROI formula (Hossain, 1999).

For all the above, ROI is a valuable ratio to estimate the profitability of firm, the convenience for investment and the efficiency of the production structure.

Comparing this accounting index with the weighted average cost of capital, finally, you will know the result of "leverage" (ROI should never be less than ROD: Return-On-Debt).

To improve the ROI is required, as well as all the efficiency ratios, leveraging on the simplification of processes. ROI is derived from the decomposition of the following important correlation of ratios (Homgren \& Sundem, 1993):

$$
\text { ROI }=\frac{\text { Ebit }}{\text { Sales }} \times \frac{\text { Sales }}{\text { Total investment }}=\text { ROS } \times \quad \text { Investment turnover }
$$

In this way is demonstrated mathematically that to increase ROI is possible to interfere directly on Return-On-Sales (ROS) or on rotation of capital invested. Generally, in conjunction with low rotations on capital employed, return on sales (ROS) is substantial. The opposite is true in case of high rotation of investments. This is often a consequence of both the specific nature of the activity performed, and the presence of particular developments in economic and productive areas that may not return high profitability in occasion of high rotations (Usry \& Hammer, 1991).

\section{Conceptual Definitions: Dataset and Explanatory Variables}

The firms analysed are small and medium-sized enterprises (SMEs) with revenues from 5 million to 50 million euro, operating in Italy. Their characteristics are summarised in Table 1. 
Table 1. Characteristics of the sample used in the research

\begin{tabular}{lcccccccc}
\hline & \multicolumn{2}{c}{ Whole Sample } & \multicolumn{2}{c}{ Bad Firms } & \multicolumn{2}{c}{ Good Firms } & \multicolumn{2}{c}{ Efficient firms } \\
\hline & $\mathrm{Nr}$ & $\%$ & $\mathrm{Nr}$ & $\%$ & $\mathrm{Nr}$ & $\%$ & $\mathrm{Nr}$ & $\%$ \\
\hline Manufacturing Firms & 3,029 & 100.00 & 140 & 4.62 & 2,889 & 95.38 & 524 & 17.30 \\
Commercial Firms & 2,359 & 100.00 & 70 & 2.97 & 2,289 & 97.03 & 388 & 16.45 \\
\hline Whole Sample & $\mathbf{5 , 3 8 8}$ & $\mathbf{1 0 0 . 0 0}$ & $\mathbf{2 1 0}$ & $\mathbf{3 . 9 0}$ & $\mathbf{5 , 1 7 8}$ & $\mathbf{9 6 . 1 0}$ & $\mathbf{9 1 2}$ & $\mathbf{1 6 . 9 3}$ \\
\hline
\end{tabular}

The reporting year of the examination is 2007. All the firms which have not been insolvent at least until the year 2010 are considered "good firms". On the other hand, firms that have become insolvent before the three years following the year of analysis have been eliminated and firms that became insolvent just during 2010 are defined "bad firms". With this approach the horizon of analysis has been set as three consecutive years.

Companies examined in this paper are those that operate for at least eight years in the specific field of trade or production (manufacturing firms and commercial firms). It excludes all other types of firms.

Firms that have been reported by the Central Credit Register of the Bank of Italy as distressed and past-due are defined "insolvent firms" referring to a standardised definition formulated by the Basel Committee. Bad firms are those that have initiated bankruptcy proceedings, those that have a serious negative act report and therefore the abovementioned insolvent firms.

In this research are described as efficient firms those that owning after three year (i.e. in the year 2010) a level of ROI greater than $8.00 \%$. That collection covers qualified firms that will show to generate a high level of value added, a strong creditworthiness and a good profitability, particularly in the long term.

With this designation the final number of firms defined as efficient firms is 912 equivalents to $16.93 \%$ on 5,388 firms of the whole sample used.

The financial ratios, which formed the explanatory variables of model, were determined by yearly statements belonging to 5,388 unique firms during year 2007 (Note 3).

\section{Descriptive Analysis}

First problem is to substantiate the existence of a direct relationship between ROI and probability of default after three years. Descriptive analysis will show that the level of ROI superior than $9 \%$ is a sufficient threshold to ensure a fair corporate profitability and a long-term solvency.

The following table shows the averages of ROI for insolvent firms and for good firms.

Table 2. Return on investment in 2007 and in 2010

\begin{tabular}{lcc}
\hline & ROI in 2007 & ROI in 2010 \\
\hline Bad firms & $3.82 \%$ & $-6.83 \%$ \\
Good firms & $6.97 \%$ & $4.46 \%$ \\
\hline
\end{tabular}

Insolvent firms in 2007, three years before default, had an average of $3.82 \%$ of ROI, while the good firms, in the same year, had an average amounting to $6.97 \%$. After three years, bad firms have found default, and thus ROI is clearly negatively affected while good firms, due to the economic downturn, however, have experienced a decline in this ratio but it is still positive.

As already mentioned in many instances, a great responsibility is attributed to their firm's financial structure. More precisely, the fault of large assets and, therefore, of shares of invested capital, lies with too much indebtedness, inconsistent with the size growth of SMEs. 


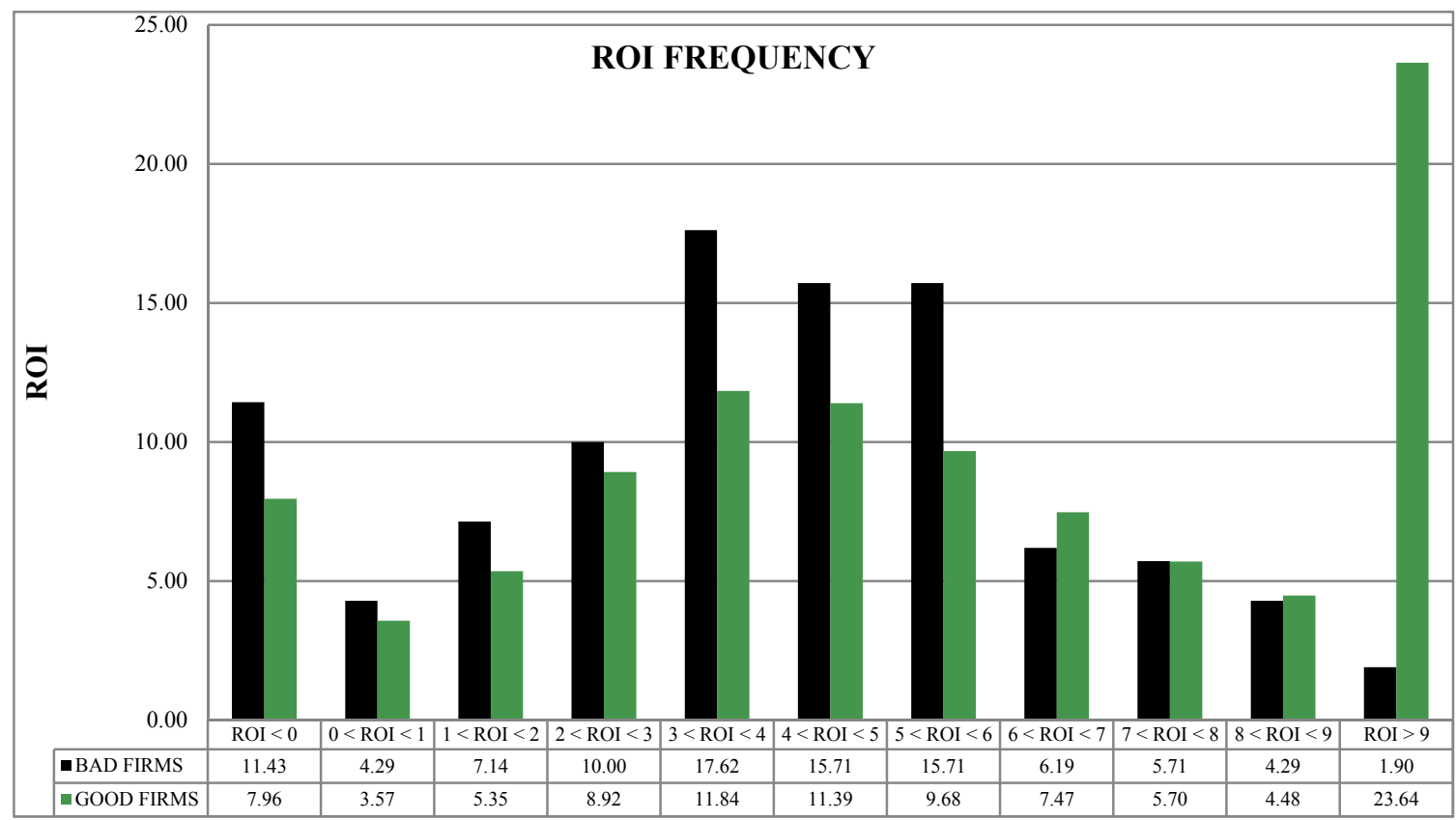

Figure 1. Distribution of firms in view of the level of ROI frequency in 2007

Figure 1 describes the progress of the frequencies of good firms and bad firms in view of the level of ROI in 2007. Graph displays that only $1.90 \%$ of insolvent firms had, three years before default, ROI higher than the $9.00 \%$ while well beyond $23 \%$ of good firms in 2007 reached this value.

At this point we define the group of firms with a ROI greater than $9.00 \%$ as creditworthy and efficient firms. With this definition, by way of support of subsequent empirical analysis, will be sought the factors that lead firms, always after three years, to reach this minimum level of ROI.

\section{Empirical Analysis}

To search the most predictive explanatory variables of the event "ROI $>9.00 \%$ after three years", we used the logistic analysis. The technique of logistic regression allows us to shape a regression function able of distinguishing efficient firms from whole sample. A logistic model is a binary choice model where the dependent variable may only assume two possible values. In this research, $p_{i}$ is included in the range $(0 ; 1)$ and denotes the probability of efficiency, which assumes the value " 1 " if the i-th firm exceeds the level of $9.00 \%$ of ROI in 2010 and the value " 0 " if it fails to overcome.

Logistic regression has functioned with a variable-reduction process known as "forward stepwise". In this process, each variable is strained, one at a time, starting from the most predictive variable by itself, until no new accounting ratios make any significant contribution to the model (until no further improvement is possible). Through this approach, the model allows a massive use of all the independent variables.

The logit regression is calculated by relying exclusively on the 46 accounting ratios calculated in 2007, three years before. In order to prevent strong correlations with the dependent variable, all the accounting ratios that have in the numerator or denominator "Operating income", "Ebit", "Total investment" were eliminated from the set of explanatory variables.

The results of the logistic regression through the forward stepwise procedure are descripeted in belove Table 3 .

Table 3. Stepwise logistic regression. Functions calculated on firms in 2007. Event: ROI $>9.00 \%$ during 2010.

\begin{tabular}{lcccc}
\hline & $\boldsymbol{\beta}$ & S.E. & Wald & $\boldsymbol{E x p}(\boldsymbol{\beta})$ \\
\hline Cash and bank deposits / Total assets & 0.026 & 0.004 & 50.821 & 1.026 \\
Inventory / Total assets & -0.015 & 0.003 & 28.386 & 0.985 \\
Borrowings / Total assets & -0.009 & 0.003 & 9.639 & 0.991 \\
Total shareholders' equity / Short term debt & -0.002 & 0.001 & 3.332 & 0.998
\end{tabular}




\begin{tabular}{lcccc} 
Total shareholders' equity / Total assets & 0.027 & 0.006 & 23.364 & 1.028 \\
Total debt / Sales & -0.012 & 0.002 & 25.806 & 0.988 \\
Return-On-Equity (ROE) & 0.009 & 0.002 & 14.225 & 1.009 \\
Gross profit / Sales & 0.139 & 0.011 & 159.946 & 1.149 \\
Cost for employees / Cost of sales & -0.162 & 0.013 & 145.759 & 0.851 \\
Depreciation and amortization / Sales & -0.077 & 0.021 & 12.997 & 0.926 \\
Total shareholders' equity / Sales & -0.018 & 0.005 & 15.513 & 0.982 \\
\multicolumn{1}{c}{$\quad$ Constant } & -1.636 & 0.211 & 59.829 & 0.195
\end{tabular}

Result of the logistic regression, exposed in the Table 3, defines a function of separation amongst "ordinary firms" and efficient firms after three years. Considering the estimated parameters it is possible to formulate the model of efficiency prediction as follows:

$\mathrm{z}=-1.636+0.026 \mathrm{x}$ (Cash and bank deposits / Total assets) $-0.015 \mathrm{x}$ (Inventory / Total assets) $-0.009 \mathrm{x}$ (Borrowings / Total assets $)-0.002 \mathrm{x}$ (Total shareholders' equity / Short term debt) $+0.027 \mathrm{x}$ (Total shareholders' equity / Total assets) $-0.012 \mathrm{x}$ (Total debt / Sales $)+0.009$ x (ROE) +0.139 x (Gross profit / Sales $)-0.162$ x (Cost for employees / Cost of sales $)-0.077 \mathrm{x}$ (Depreciation and amortization / Sales) $-0.018 \times$ (Total shareholders' equity / Sales).

You can note that coefficients of "Cash and bank deposits / Total assets", "Total shareholders' equity / Total assets", "Roe" and "Gross profit / Sales", are positive. This means that when these accounting ratios growth, the probability of finding a firm with ROI greater than $9 \%$ increases. These explanatory variables have also a considerable statistical significance confirming the predictive power of the profitability ratios.

Other coefficients are negative. They mainly concern the components of the assets or the extent of debt or equity. Higher assets, in fact, imply a slower rotation of investments and, therefore, a lower ROI. It is logical also the behaviour of labor costs or amortization on sales because they just depress the corporate earnings. Quotient made by equity and short-term debt has a low statistical significance and a sign of coefficient (negative) not entirely explicable (Note 4).

The structure of ranking scale occurs in connection with the logistic function remarked in table 3 . Given the coefficients for a set of explanatory variables we can foresee the probability that each observation belongs to class of efficient firms. Ranking scale determines the subdivision of the sample into ten ordinal classes equally numerous where 1 is best, 10 is worst, and each quantity corresponds to an addition of 10 percentage points (Note 5).

Returning to the default cases after three years, graph 2 shows the distribution of insolvencies within the ten ordinal classes built with the statistical model described above.

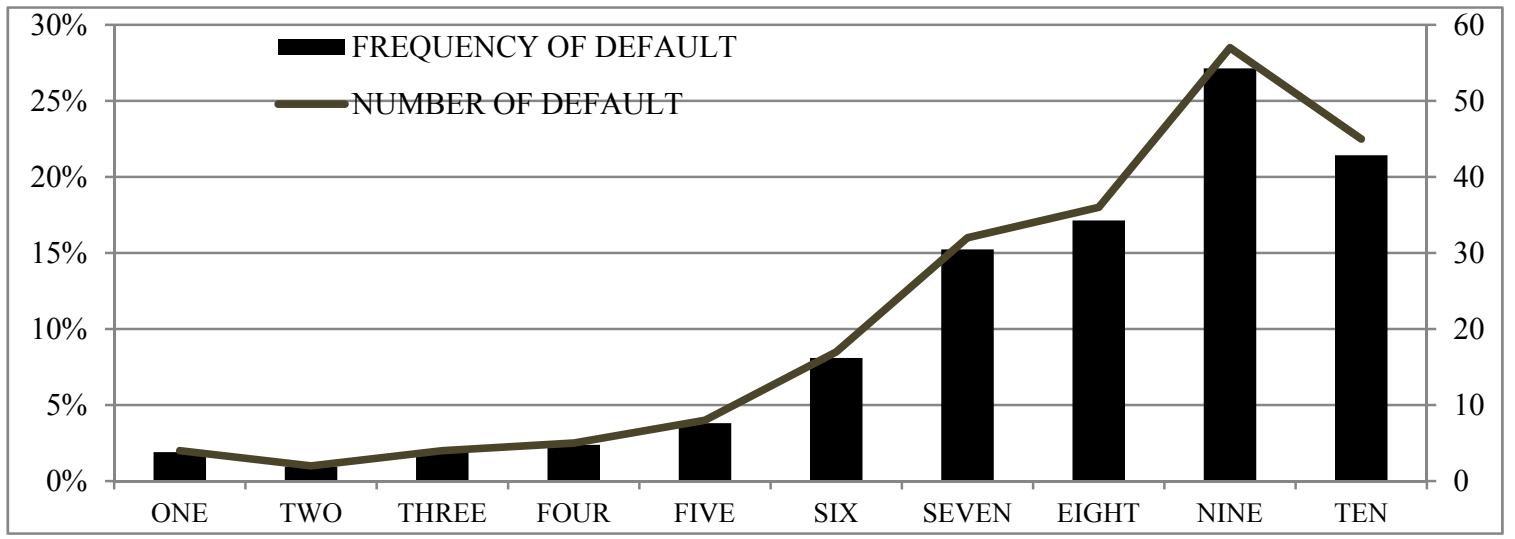

Figure 2. Frequency of defaults

To complete the research, the firms included in the top three classes of ranking will be isolated from the remaining part of the sample. They will be defined as firms that are most likely to achieve a ROI greater or equal than $9 \%$ after 
three years. They will be referred to as "prospective efficient." On the other hand, firms classified in the remaining seven classes of probability ( $70 \%$ of the total sample) will be referred to as "ordinary firms".

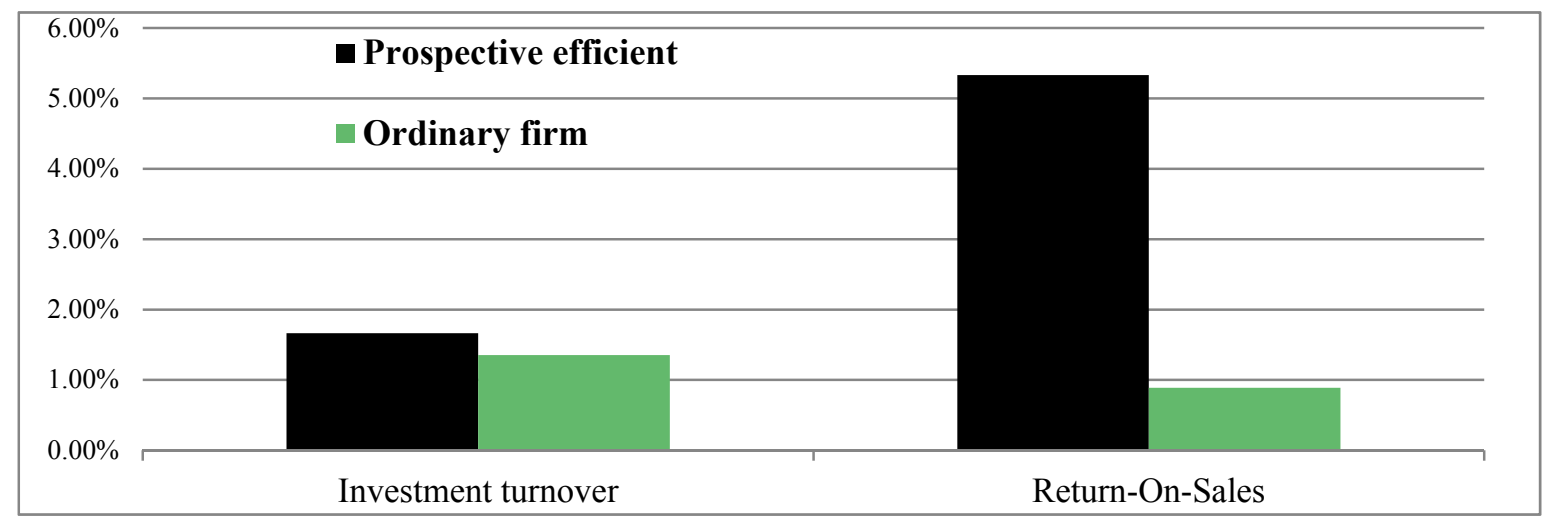

Figure 3. Breakdown of the ROI

By this definition we first see the impact of the two factors constituting the ROI calculation. Figure 3, in fact, displays that difference between the two groups of firms is not so much in investment turnover but rather in Return-On-Sales (ROS). The prospective efficient firm reaches a mean ROS after three years amounting 5.33\% against ordinary firms that stop to $0.9 \%$. Turnover rate of investment, however, does not show a substantial dissimilarity.

Another essential aspect in the quest for efficiency is the optimal capital structure. In this it should be noted that there were also many empirical studies (Muscettola, 2014a) that have investigated the correct mixture that leads firms to be efficient and creditworthy over time. Figure 4 and Figure 5 point out the differences in the composition of sources amongst the two groups of firms.

Figure 4 illustrates capital structure of the prospective efficient company. It describes how this firm is better capitalized than ordinary enterprise (Figure 5). The dissimilarities are mainly in Net worth and in financial debts. The companies that will be efficient, therefore, have a lower debt and greater recourse to equity.

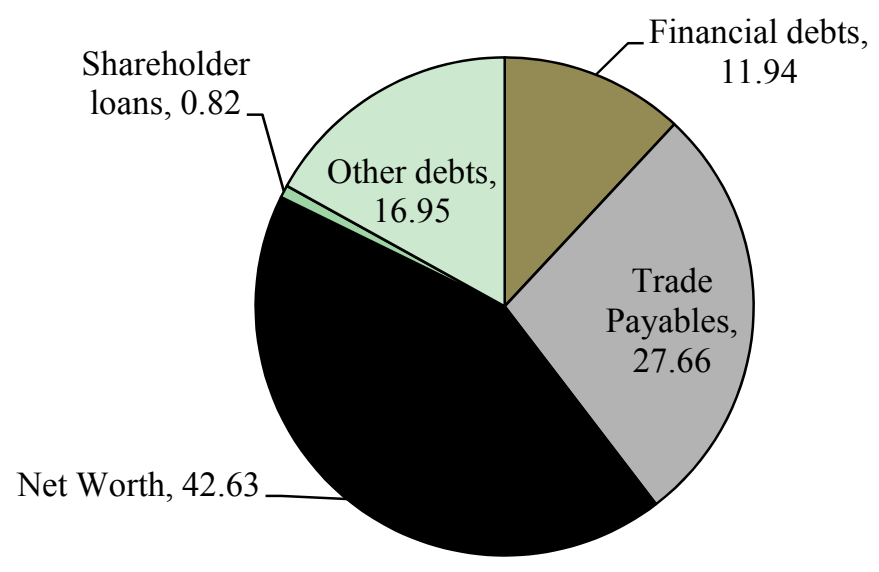

Figure 4. Capital structure of the prospective efficient firms 


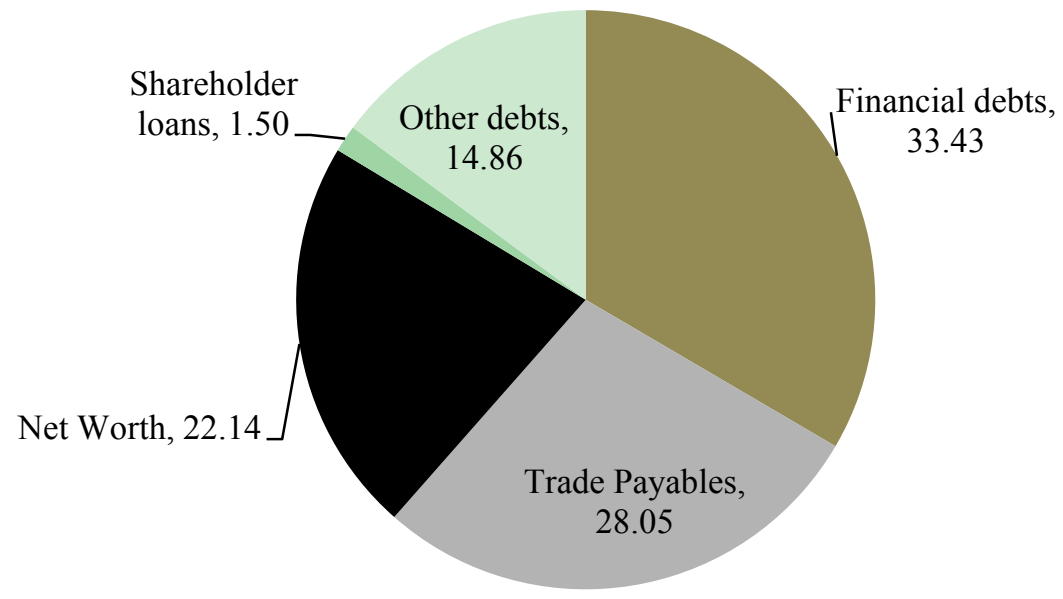

Figure 5. Capital structure of the ordinary firms

Finally, Figure 6 highlights the remaining part of the accounting ratios differentiating the sample of firms in ordinary firms and in prospective efficient ones. In this case the technique of normalization of averages stands for fitting into a single graph indexes with different parameters. Standard scores (Note 6) enable scores from dissimilar examinations to be compared on a mutual scale. With such modelling technique is practicable to match the means of accounting ratios in a unique chart.

$\longrightarrow$-Prospective efficient $\quad \longrightarrow$ - Ordinary firm

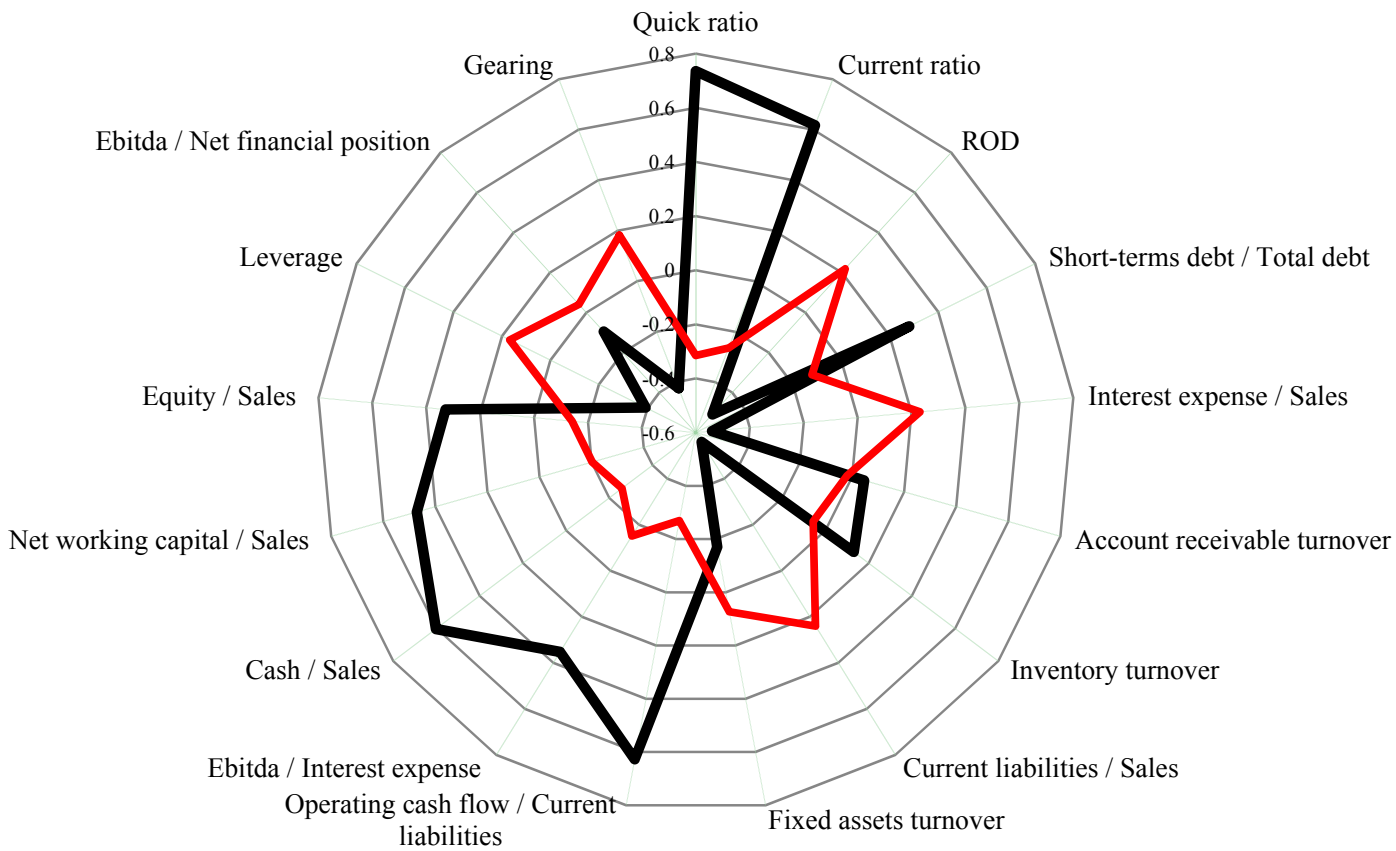

Figure 6. Distribution of normalized averages of prospective efficient firms and ordinary firms 


\section{Conclusions}

As you can imagine, to have the opportunity to select in advance firms that have a potential to be exploited in development means to optimize scarce resources. On the one hand, that also means to accelerate the economic growth of local economy. Although it is a cliché that there is no efficient firm, the problem often encountered is that financial institutions, banks in particular, neglect the definition of "relation rating" while, on the other hand, they rest to observe the possibility of default starting, and ending, with the past and with the statistics gathered. In other words, the banks now use almost exclusively a "counterparty rating". It is based on the transaction, with a view to short-term and limited to objective variables (Muscettola \& Pietrovito, 2012a) which, moreover, are indirectly affected by the economic contingent moment. Transaction rating, in fact, is not weighted to avoid the phenomenon of pro-cyclicality.

Returning to the problem, and evoking that by viewing the structural differences and the dissimilar results it is easier to find the gear to move to improve something., it is possible attempt to reconstruct, in other places and in other firms, the financial structure that over three years leads firms to be more efficient. Performance measure is considered as essential because of dearth of resources by the economic parts. To subsist in a cutthroat market like the current one, firms have to ensure best employment of their capitals.

Results of this paper add to the recent stream of empirical literature on the effects of higher quality reporting over investment efficiency an essential aspect concerning the accounting basis that statistically should have a private company to become efficient over time.

Findings suggest that it is possible to predict statistically a firm that will be efficient and, in all likelihood, it will also be solvent. Companies that have a heavy indebtedness (Muscettola, 2014c) are less likely to fall into the group of efficient firms. Also, the evidence does not support the effectiveness of the indices of rotation in the prediction of predictive efficient.

Notwithstanding what are the most predictive indicators of efficiency, it would be a landmark if the banks, beside the aforementioned counterparty rating that measures the probability of default, added a selection model of firms based on the calculation of the probability of efficiency. In this way it would develop firms that generate greater added value, optimizing the available resources, with positive impacts in terms of wealth also towards and from the surrounding territory.

\section{References}

Aigner, D. C. A., Knox, L., \& Schmidt, P. (1977). Formulation and Estimation of Stochastic Frontier Production Function Models. Journal of Econometrics, 6, 21-37. http://dx.doi.org/10.1016/0304-4076(77)90052-5

Basel Committee. (2005). Validation of low-default portfolios in the Basel II Framework, September 2005, Bank for International Settlement, 2005.

Battese, G. M., \& Corra, G. H. (1977). Estimation of Production Frontier Models With Application to the Pastoral Zone of Eastern Australia. Australian Journal of Agricultural Economics, 21, 167-179. http://dx.doi.org/10.1111/j.1467-8489.1977.tb00204.x

Beatty, A., Liao, S., \& Weber, J. (2010). The effect of private information and monitoring on the role of accounting quality in investment decisions. Contemporary Accounting Research. http://dx.doi.org/10.1111/j.1911-3846.2010.01000.x

Biddle, G.C., \& Hilary, G. (2006). Accounting quality and firm-level capital investment. The Accounting Review, 81(5), 963-982. http://dx.doi.org/10.2308/accr.2006.81.5.963

Biddle, G.C., Hilary, G., \& Verdi, R. S. (2009). How does financial reporting quality improve investment efficiency? Journal of Accounting and Economics, 48, 112-131. http://dx.doi.org/10.1016/j.jacceco.2009.09.001

Block, S. B., \& Hirt, G. A. (2002). Foundations of Financial Management. McGraw-Hill Irwin.

Charnes, A., Cooper, W., \& Rhodes, E. (1978). Measuring the Efficiency of Decision Making Units. European Journal of Operational Research, 2, 429-444. http://dx.doi.org/10.1016/0377-2217(78)90138-8

Chatterjee, S. (2010). The Impact of Working Capital Management on the Profitability of the Listed Companies on the London Stock Exchange. Working Paper Series, SSRN.

Chen, Q., Hemmer, T., \& Zhang, Y. (2007). On the relation between conservatism in accounting standards and incentives for earnings management. Journal of Accounting Research, 45(3), 541-565. http://dx.doi.org/10.1111/j.1475-679X.2007.00243.x 
Cooper, W. W., Seiford, L. M., \& Zhu, J. (2004). Handbook of Data Envelopment Analysis. Kluwer Academic Publishers: Boston, MA.

Cummins, J. D., \& Weiss, M. A. (2012). Analyzing Firm Performance in the Insurance Industry Using Frontier Efficiency and Productivity Methods. Handbook of Insurance Economics.

Dominiak, G. F., \& Louderback, J. G. (1985). Managerial Accounting. Kent Publishing Company.

Färe, R., Grosskopf, S., \& Margaritis, D. (2008). Efficiency and Productivity: Malmquist and More. In H.O. Fried, C.A.K. Lovell, and S.S. Schmidt (Eds.), The Measurement of Productive Efficiency and Productivity Growth. Oxford University Press: New York. http://dx.doi.org/10.1093/acprof:oso/9780195183528.003.0005

Farrell, M. J. (1957). The Measurement of Productive Efficiency. Journal of the Royal Statistical Society A, 120, 253-281.

Greene, W. H. (2008). The Econometric Approach To Efficiency Analysis. In Hal O. Fried, C.A. Knox Lovell, and Shelton S. Schmidt (Eds.), The Measurement of Productive Efficiency and Productivity Growth. Oxford University Press: New York.

Homgren, C. T., \& Sundem, G. L. (1993). Introduction to Management Accounting. Prentice-Hall of India; 9th Edition.

Jensen, M. (1986). Agency Costs of Free Cash Flow, Corporate Finance, and Takeovers. American Economic Review, $76,323-329$.

Kanodia, C., Singh, R., \& Spero, A. (2005). Imprecision in Accounting Measurement: Can it be value enhancing? Journal of Accounting Research, 43, 487-519. http://dx.doi.org/10.1111/j.1475-679X.2005.00178.x

McNichols, M. F., \& Stubben, S. R. (2008). Does earnings management affect firms' investment decisions? The Accounting Review, 83(6), 1571-1603. http://dx.doi.org/10.2308/accr.2008.83.6.1571

Mohammad, F. H. (1999). Who are More Concerned about the ROI, Academics or Firms? Journal of Business Research, 2.

Muscettola, M. (2013). Leverage Risk. The weight of borrower capital distinguishes the solvency of firms: an empirical analysis on a sample of 4,500 Italian SMEs. International Journal of Economics and Finance, 5(12). http://dx.doi.org/10.5539/ijef.v5n12p24

Muscettola, M. (2014a). Structure of assets and capital structure. What are the relations with each other? An empirical analysis of a sample of Italy. European Journal of Economics and Finance, 5(12).

Muscettola, M. (2014b). Cash conversion cycle and firm's profitability. An empirical analysis on a sample of 4,226 manufacturing SMEs of Italy. International Journal of Business and Management, 9(5). http://dx.doi.org/10.5539/ijbm.v9n5p25

Muscettola, M. (2014c). Effects of fixed capital investments in current economic downturn. International Journal of Business and Management, 5(9).

Muscettola, M., \& Gallo, M. (2008). Analisi e gestione del rischio di credito. Il progetto Mayflower. FrancoAngeli Editore.

Muscettola, M., \& Naccarato, F. (2013). Probability of Default and Probability of Excellence, an Inverse Model of Rating. One More Tool to Overcome the Crisis: an Empirical Analysis. Business System Review, 2(2). http://dx.doi.org/10.7350/BSR.BV06.2013

Muscettola, M., \& Pietrovito, F. (2012a). Le caratteristiche delle imprese insolventi. Sinergie Rapporti di ricerca, 36.

Muscettola, M., \& Pietrovito, F. (2012b). La rilevanza delle variabili finanziarie nel rating: i risultati di un'analisi empirica sulle PMI italiane. Sinergie Rapporti di ricerca, 36.

Myers, S., \& Majluf, N. (1984). Corporate Financing and Investment Decisions When Firms Have Information That Investors Do Not Have. Journal of Financial Economics, 13, 187-221. http://dx.doi.org/10.1016/0304-405X(84)90023-0

Polimeni, R. S., Fabozzi, F. J., \& Adelberg, A. H. (1991). Cost Accounting, Concepts and Applications for Managerial Decision Making (3rd ed.). McGraw-Hill, Inc.

Schall, L. D., \& Haley, C. W. (1991). Introduction to Financial Management (6th ed.). McGraw-Hill. 
Usry, M. F., \& Hammer, L. H. (1991). Cost Accounting, Planning and Control (10th ed.). South-Western Publishing Co.

\section{Notes}

Note 1. The most elementary efficiency notion is production frontier. It designates the minimum inputs essential to produce any given level of production for a firm working with complete efficiency.

Note 2. Cost minimization comprises the minimization of input usage conditional on the production, and revenue of sales minimization comprises maximization of productions conditional on the input

Note 3. The yearly statements are provided by Crif Spa. As for the creation of the statistical model, the initial processes on the data, the choice of the outliers and the formation of accounting ratios, the reader ought to refer exclusively to the author.

Note 4. It often happens that few indicators in a logistic regression lose a part of their "predictive logic" if taken so assembled.

Note 5 . For each observation we would have $10 \%$ probabilities of fitting to each of the ten classes.

Note 6. As such, each raw score may be given an equivalent "z-score". A score that is exactly on the mean of whole sample corresponds to a $\mathrm{z}$ of 0 . 